\title{
Inbreeding depression of 28 maize elite open pollinated varieties
}

\author{
Cleso Antônio Patto Pacheco ${ }^{1}$, Manoel Xavier dos Santos ${ }^{1}$, Cosme Damião Cruz ${ }^{2}$, Sidney Netto Parentoni ${ }^{1}$, \\ Paulo Evaristo de Oliveira Guimarães ${ }^{1}$, Elto Eugênio Gomes e Gama ${ }^{1}$, Álvaro Eleutério da Silva ${ }^{1}$, \\ Hélio Wilson Lemos de Carvalho ${ }^{3}$ and Pedro Abel Vieira Júnior ${ }^{4}$ \\ ${ }^{1}$ Embrapa Milho e Sorgo, Sete Lagoas, MG, Brazil. \\ ${ }^{2}$ Universidade Federal de Viçosa. \\ ${ }^{3}$ Embrapa Tabuleiros Costeiros. \\ ${ }^{4}$ Embrapa SPSB Gerencia Local de Ponta Grossa.
}

\begin{abstract}
The study of inbreeding depression is important for breeding strategies such as use of inbred progenies or extraction of inbreed lines. A diallel of 28 maize open-pollinated varieties was evaluated in 10 environments in the early 1990 s. At the same time, $\mathrm{S}_{1}$ populations for each of the 28 varieties were evaluated in the same 10 experiments (environments). Yield reductions of the populations from $S_{0}$ to $S_{1}$ (mean of the 10 environments), varied from 34.6\% (CMS-01) to $59.2 \%$ (CMS-30), with an average of $49.1 \%$. Inbreeding depression was greater in populations with a wider genetic base, which had never been exposed to inbreeding (CMS-30, BR-107, PH4, Cunha, Saracura, Nitrodent, and Nitroflint). Inbred lines with greater yield means should be obtained from the BR-105, BR-111, CMS-01, CMS-03, BR-106, CMS-14c, and CMS-28 populations. The use of parameter estimates generated by analysis of inbreeding depression, allow to make inferences about frequencies of deleterious alleles in the population. The frequencies of favorable alleles in the parents can be obtained by diallel analysis. The association of these two types of information, can provide a better interpretation of the genetic parameters and also can improve the process of selection of parents for either an intra- or an inter-populational breeding program.
\end{abstract}

Key words: inbreeding depression, endogamy, maize, breeding, diallel.

Received: April 19, 1999; accepted: May 5, 2002.

\section{Introduction}

In maize, as in other open-pollinating plants, the predominance of intercrossing among population individuals enables heterozygote types to prevail and deleterius, normally recessive, genes to remain hidden in the population by heterozygosis. The frequency of these deleterius alleles, which varies from population to population, is called genetic load (Vencovsky and Barriga, 1992). In spite of the importance of self-pollination in maize breeding, in Brazil relatively few results exist on inbreeding depression, a genetic phenomenon first explained in Shull's work in 1908 (Hallauer and Miranda Filho, 1988). The well-known gain in hybrid vigor from crossing of inbred lines contrasts with the inbreeding depression problem resulting from continuous self-pollination which may greatly restrict frequency of useful lines extractable from a population. Inbreeding depression for any characteristic results from the difference

Send correspondence to Cleso A.P. Pacheco. Embrapa Milho e Sorgo, Caixa Postal 151, 35701-970 Sete Lagoas, MG, Brazil. E-mail: cleso@ cnpms.embrapa.br. between expressed and total genetic load, where the expressed load is defined under random mating and the total load includes one hidden by heterozygosis and revealed by self-pollination (Crow and Kimura (1970), quoted by Lima et al., 1984).

A fairly simple additive-dominant model proposed by Gardner (1965) has been used to determine the inbreeding depressions of maize populations and to identify those populations of greater potential for line extraction. Based on the difference between the mean of the open pollinated population $\left(\mathrm{P}_{\mathrm{i}}\right)$ or $\mathrm{S}_{0}$ generation and the mean of the same population after a generation of self pollination $\left(\mathrm{S}_{1 \mathrm{i}}\right)$, this procedure was used by Vianna et al. (1982) for analysis of 14 maize populations and by Lima et al. (1984) for analysis of 32 cultivars. The model is described in detail by Vencovsky and Barriga (1992).

The maximum expected depression of one self-pollinated generation in relation to the $\mathrm{S}_{0}$ generation is $50 \%$. The greatest criticism of the Gardner model has been the negative estimates for the expression $\hat{u}+\hat{a}=2 S_{1 i}-S_{0 i}$, which estimates the mean of all possible randomly extracted lines 
Table I. Characteristics of the 28 parental populations from the maize breeding program of Embrapa Maize and Sorghum Research Center.

\begin{tabular}{|c|c|c|c|c|}
\hline Populations* & Cycles of selection ${ }^{\mathrm{a}}$ & Grain color $^{\mathrm{b}}$ & Grain texture $^{c}$ & Maturaty $^{\mathrm{d}}$ \\
\hline 01- CMS 1 (Mezcla Amarilla) & 1 & $\mathrm{Y}$ & $\mathrm{SF}$ & I \\
\hline 02- CMS 2 (Antigua x Vera Cruz) & 1 & $\mathrm{Y}$ & $\mathrm{SD}$ & I \\
\hline 03- CMS 3 (Amarillo Cristalino) & 1 & Y & $\mathrm{F}$ & I \\
\hline 04- CMS 4N (Amarillo Dentado N) & 9 & Y & $\mathrm{D}$ & I \\
\hline 05- CMS 4C (Amarillo Dentado C) & 6 & $\mathrm{Y}$ & $\mathrm{D}$ & I \\
\hline 06- BR 105 (Suwan DMR) & 9 & $\mathrm{O}$ & $\mathrm{F}$ & I \\
\hline 07- BR 106 & 9 & $\mathrm{Y}$ & SD & I \\
\hline 08- BR 107 & 8 & $\mathrm{O}$ & $\mathrm{F}$ & I \\
\hline 09- BR 111 (Pool 21) & 5 & $\mathrm{Y}$ & $\mathrm{F}$ & I \\
\hline 10- BR 112 (Pool 22) & 5 & $\mathrm{Y}$ & SD & I \\
\hline 11- CMS 14C (Pool 25) & 5 & $\mathrm{Y}$ & $\mathrm{SF}$ & I \\
\hline 12- CMS 15 (Pool 26) & 1 & $\mathrm{Y}$ & $\mathrm{D}$ & $\mathrm{L}$ \\
\hline 13- CMS 22 (Amarillo del Bajio) & 8 & $\mathrm{Y}$ & SD & I \\
\hline 14- CMS 23 (Antig. x Rep.Dominic.) & 1 & $\mathrm{Y}$ & $\mathrm{D}$ & $\mathrm{E}$ \\
\hline 15- BR 126 & 11 & $\mathrm{Y}$ & $\mathrm{D}$ & $\mathrm{L}$ \\
\hline 16- CMS 28 & 6 & $\mathrm{Y}$ & $\mathrm{SD}$ & I \\
\hline 17- CMS 29 (A.del Bajio x Templados) & 1 & $\mathrm{Y}$ & $\mathrm{SF}$ & I \\
\hline 18- CMS 30 & 8 & $\mathrm{Y}$ & SD & $\mathrm{L}$ \\
\hline 19- BR 136 & 6 & $\mathrm{Y}$ & $\mathrm{SF}$ & $\mathrm{L}$ \\
\hline 20- CMS 39 & 5 & $\mathrm{Y}$ & $\mathrm{D}$ & $\mathrm{L}$ \\
\hline 21- CMS 50 & 2 & $\mathrm{Y}$ & $\mathrm{SD}$ & I \\
\hline 22- Sintético Elite & 1 & $\mathrm{Y}$ & $\mathrm{SD}$ & I \\
\hline 23- África do Sul ph4 & 1 & $\mathrm{Y}$ & $\mathrm{F}$ & $\mathrm{E}$ \\
\hline 24- Cunha & BAG & $\mathrm{Y}$ & $\mathrm{D}$ & $\mathrm{L}$ \\
\hline 25- BA III - Tusón & BAG & $\mathrm{Y}$ & $\mathrm{D}$ & $\mathrm{L}$ \\
\hline 26- Composto Saracura & 3 & $\mathrm{Y}$ & $\mathrm{F}$ & I \\
\hline 27- Nitroflint & 4 & $\mathrm{Y}$ & $\mathrm{F}$ & $\mathrm{L}$ \\
\hline 28- Nitrodent & 4 & $\mathrm{Y}$ & $\mathrm{D}$ & $\mathrm{L}$ \\
\hline
\end{tabular}

a: $\mathrm{BAG}=$ active germplasm bank; $\mathrm{b}: \mathrm{Y}=$ yellow; $\mathrm{O}=$ orange; $\mathrm{c}: \mathrm{F}=$ flint; $\mathrm{SF}=$ semi-flint; $\mathrm{SD}=$ semi-dent; $\mathrm{D}=$ dent; $\mathrm{d}$ : $\mathrm{E}=$ early; $\mathrm{I}=$ intermediate; $\mathrm{T}=$ late $* \mathrm{BR}=$ commercial variety; $\mathrm{CMS}=$ experimental population.

from a population $\mathrm{i}$. The negative values for the estimates of $\left(\hat{\mathrm{u}}+\hat{\mathrm{a}}=2 \mathrm{~S}_{1 \mathrm{i}}-\mathrm{S}_{0 \mathrm{i}}\right.$ ), according to Lima et al. (1984), can be attributed either to experimental errors or to a homozygosis higher than expected. Crow and Kimura (1970) justify this second factor by referring to a special type of epistasis; i.e., the harmful effects of two loci are more than cumulative, so that with inbreeding increase, population performance decreases at a greater rate than that predicted by the model without epistasis. This explanation is similar to that of Vencovsky and Barriga (1992).

In spite of the model's limitations, important conclusions regarding the inbreeding percentage and population constitution were made by Vianna et al. (1982) and Lima et al. (1984). These authors concluded that lower genetic loads are expected in populations synthesized from inbred lines and in wide-base composites that have already passed through some selection process against harmful alleles, compared with those from highly heterozygous populations never exposed to any level of inbreeding. In these latter populations lethal and recessive alleles remain hidden in the heterozygotes.

The importance of inbreeding depression versus environment interaction has also been shown, mainly in the study by Lima et al. (1984), indicating that the manifestation of inbreeding effects may vary among environments. Error variance heterogeneity in the study by Vianna et al. (1982) precluded joint analysis, but the authors commented on differences in the ranking of the genetic material among environments.

\section{Material and Methods}

The 28 open-pollinated populations (Ps), their 378 interpopulational hybrids $\left(\mathrm{F}_{1}\right.$, s $)$, the first self-pollination generation $\left(\mathrm{S}_{1}\right.$ 's $)$ from each of the 28 populations, and seven 
commercial checks were evaluated in 10 Brazilian environments. Seeds of the $28 \mathrm{Ps}$, the $378 \mathrm{~F}_{1}$ 's, and the $28 \mathrm{~S}_{1}$ 's were obtained at Embrapa Maize and Sorghum Research Center, in Sete Lagoas, MG, in the winter of 1990 and 1991. At least 60 crossings, 70 sibs, and 70 self-pollinations were obtained, respectively, to represent each $\mathrm{F}_{1}$, each population per se, and each $\mathrm{S}_{1}$ generation. Within each material, selected ears were harvested and shelled together and the seeds mixed and homogenized to make a single sample for trials. The checks seeds were provided by commercial companies. Table 1 includes some agronomic characteristics of the 28 populations.

The trials were conducted in 21 x 21 simple lattice design in experimental areas of the National Research Center for Maize and Sorghum in Sete Lagoas, (MG), and in two other Research Centers of Embrapa located in Londrina, PR (Soybean Center) and Goiânia, GO (Rice and Bean Center). These areas represent Southeast and Centralwest Brazilian regions. Plots included two $5.0 \mathrm{~m}$ rows, spaced between rows $1.0 \mathrm{~m}$, in the agricultural years 1991/92 and 1992/93. Two other experiments were conducted at the Coastal Areas National Center in Aracaju (SE), representing the Northeast, in 1991/92 and 1993/94, and other two at the Basic Seed Production Service in Ponta Grossa (PR), representing the Southern region, in 1992/93 and 1993/94. A total of 10 environments was used.

Ear yield data (kg/ha) were corrected to $14.5 \%$ moisture prior to the statistical analyses. Individual variance analyses were performed for each environment to obtain adjusted means of treatments and effective errors. Adjusted treatment means and a randomized complete block model were used for combined analysis of the 10 environments. Average of the individual analyses of variance residuals was used as the experimental error. Environments and populations were considered as random and fixed effects, respectively.

The following model was used in the combined analysis:

$$
\mathrm{y}_{\mathrm{ijk}}=\mu+g_{\mathrm{i}}+\mathrm{a}_{\mathrm{j}}+(\mathrm{ga})_{\mathrm{ij}}+\bar{\varepsilon}_{\mathrm{ij}}
$$

Table II - Combined analysis of variance for the 10 environments, with adjusted means of the 28 parents, their 378 inter varietal hybrids, 28 S1's and seven checks. Ear weight (kg/ha) in 10 environments (1991/92 and 1992/93).

\begin{tabular}{|c|c|c|c|c|}
\hline Sources of variation & Degrees of freedom & Sum of squares & Mean square & $\mathrm{F}$ \\
\hline Environments (E) & 9 & 27131576320 & 3014619648 & $142.41 * *$ \\
\hline Treatments (T) & 440 & 11952547840 & 27164882 & $16.78 * *$ \\
\hline Diallel (D) & 405 & 3833901824 & 9466424 & $5.85 *$ \\
\hline $\mathrm{F}_{1}$ 's & 377 & 3068670720 & 8139710 & $5.03 * *$ \\
\hline $\mathrm{S}_{0}$ 's & 27 & 520497984 & 19277704 & $11.91 * *$ \\
\hline $\mathrm{S}_{1}$ 's & 27 & 228345760 & 8457250 & $5.22 * *$ \\
\hline$\left(\mathrm{S}_{0}-\mathrm{S}_{1}\right)$ & $(27)$ & 206111136 & 7633746 & $4.14 * *$ \\
\hline $\operatorname{Cov}\left[\left(S_{1},\left(S_{0}-S_{1}\right)\right]\right.$ & $(27)$ & 43021728 & 1593397 & \\
\hline Checks (C) & 6 & 117279128 & 19546522 & $12.07 * *$ \\
\hline $\mathbf{T} \times \mathbf{E}$ & 3960 & 6410868736 & 1618906 & $1.63 * *$ \\
\hline $\mathrm{D} \times \mathrm{E}$ & 3645 & 5594575872 & 1534863 & $1.55 * *$ \\
\hline $\mathrm{F}_{1}$ 's $\mathrm{x} \mathrm{E}$ & 3393 & 5138250752 & 1514368 & $1.53 * *$ \\
\hline $\mathrm{S}_{0}$ 's x E & 243 & 421869632 & 1736089 & $1.75^{* *}$ \\
\hline $\mathrm{S}_{1}$ 's X E & 243 & 172484256 & 709811 & $0.72 \mathrm{~ns}$ \\
\hline$\left(S_{0}-S_{1}\right) \times E$ & $(243)$ & 447878304 & 1843120 & $1.86 * *$ \\
\hline $\operatorname{Cov}\left[\left(S_{1},\left(S_{0}-S_{1}\right)\right] \times E\right.$ & $(243)$ & -99241280 & -408400 & \\
\hline $\mathrm{C} \times \mathrm{E}$ & 54 & 166298912 & 3079609 & $3.11^{* *}$ \\
\hline Effective error & 4000 & 3963328800 & 990832 & \\
\hline \multirow[t]{2}{*}{ Groups of treatments } & Means & $\%$ relative & \multicolumn{2}{|c|}{ Range } \\
\hline & & & Less productive & More productive \\
\hline 28 Progenitors & 6458 & 100.0 & 3865 & 8157 \\
\hline 378 F1’s & 7144 & 110.6 & 5170 & 9034 \\
\hline $28 \mathrm{~S} 1$ 's & 3285 & 50.9 & 2119 & 4971 \\
\hline 7 Checks & 7943 & 123.0 & 6333 & 9570 \\
\hline 441 Treatments & 6868 & 106.3 & 2119 & 9570 \\
\hline
\end{tabular}


Table III - Estimates of the general and specific combining ability effects, inbreeding depression and its stability coefficients for ear weight (kg/ha) of the 28 maize populations assessed in the diallel in 10 environments.

\begin{tabular}{|c|c|c|c|c|c|c|c|c|c|c|}
\hline Parental populations & $\hat{\overline{\mathrm{S}}}_{\mathrm{i}}$ & $\hat{\overline{\mathrm{g}}}_{\mathrm{i}}$ & $\hat{\overline{\mathrm{S}}}_{\mathrm{i}}$ & $\hat{\mathrm{u}}+\hat{\mathrm{a}}$ & $\hat{\overline{\mathrm{S}}}_{\mathrm{i}}-\hat{\overline{\mathrm{S}}}_{\mathrm{i}}$ & $\mathrm{ID} \%$ & $\beta_{1}$ & $\mathrm{~F}_{\mathrm{dev}}$ & $\mathrm{R}^{2}$ & $\hat{\overline{\mathrm{S}}}_{\mathrm{i}}$ \\
\hline 01 - CMS 01 & 4744.8 & -515.8 & 3103.6 & 1462.5 & 1641.2 & 34.6 & $0.09 * *$ & 1.63 & 0.6 & -1320.0 \\
\hline 02 - CMS 02 & 5486.8 & -392.0 & 2921.8 & 356.8 & 2565.0 & 46.8 & 0.71 & 0.69 & 50.6 & -825.6 \\
\hline 03 - CMS 03 & 6050.9 & -198.6 & 3718.8 & 1386.7 & 2332.1 & 38.5 & 0.92 & $2.12 *$ & 35.6 & -648.4 \\
\hline 04 - CMS 04 N & 7550.5 & 250.3 & 3725.2 & -100.2 & 3825.4 & 50.7 & $1.56^{*}$ & $2.13 *$ & 61.4 & -46.5 \\
\hline 05 - CMS 04 C & 7012.0 & 104.4 & 3474.5 & -63.0 & 3537.5 & 50.5 & $1.73^{*}$ & $2.17 *$ & 65.5 & -293.3 \\
\hline 06 - BR 105 & 8156.6 & 533.7 & 4971.0 & 1785.4 & 3185.6 & 39.1 & 1.31 & $3.14 * *$ & 43.4 & -7.3 \\
\hline 07 - BR 106 & 7785.0 & 868.6 & 4423.6 & 1062.2 & 3361.4 & 43.2 & 0.76 & 1.70 & 32.3 & -1048.7 \\
\hline 08 - BR 107 & 6586.8 & -227.5 & 2740.7 & -1105.5 & 3846.1 & 58.4 & 1.47 & 0.71 & 80.8 & -54.7 \\
\hline 09 - BR 111 & 6619.6 & 43.3 & 4176.2 & 1732.8 & 2443.4 & 36.9 & 1.17 & 0.96 & 66.4 & -563.4 \\
\hline 10 - BR 112 & 6400.4 & -189.2 & 3380.0 & 359.6 & 3020.4 & 47.2 & 0.90 & $2.22 *$ & 33.8 & -317.6 \\
\hline 11 - CMS 14 C & 6771.0 & 179.4 & 3813.5 & 855.9 & 2957.6 & 43.7 & 1.46 & $2.05 *$ & 59.0 & -684.2 \\
\hline 12 - CMS 15 & 6951.0 & -222.2 & 3304.2 & -342.5 & 3646.7 & 52.5 & 0.90 & 1.14 & 49.9 & 299.0 \\
\hline 13 - CMS 22 & 6063.5 & -162.8 & 2866.6 & -330.2 & 3196.8 & 52.7 & 0.99 & 0.42 & 76.6 & -707.4 \\
\hline 14 - CMS 23 & 5344.6 & -692.4 & 2523.5 & -297.6 & 2821.1 & 52.8 & 1.12 & $2.01 *$ & 46.4 & -367.1 \\
\hline 15 - BR 126 & 5352.1 & -78.7 & 2547.3 & -257.6 & 2804.9 & 52.4 & 1.24 & 1.56 & 57.8 & -1586.9 \\
\hline 16 - CMS 28 & 6648.2 & 226.2 & 3625.0 & 601.9 & 3023.2 & 45.5 & $1.65^{*}$ & 1.21 & 75.8 & -900.7 \\
\hline 17 - CMS 29 & 6279.3 & -352.8 & 3108.6 & -62.1 & 3170.7 & 50.5 & 0.87 & 0.91 & 53.7 & -111.6 \\
\hline 18 - CMS 30 & 5996.0 & -250.6 & 2446.0 & -1103.9 & 3550.0 & 59.2 & 0.48 & 1.54 & 17.4 & -599.2 \\
\hline 19 - BR 136 & 6362.1 & -18.4 & 2952.6 & -456.8 & 3409.5 & 53.6 & 1.09 & 0.97 & 63.0 & -697.6 \\
\hline 20 - CMS 39 & 7062.3 & 246.4 & 3644.2 & 226.0 & 3418.1 & 48.4 & 0.28 & $5.33 * *$ & 1.9 & -526.9 \\
\hline $21-\mathrm{CMS} 50$ & 6670.1 & 345.0 & 3266.2 & -137.6 & 3403.9 & 51.0 & 1.00 & $2.55^{* *}$ & 35.5 & -1116.4 \\
\hline 22 - Sint. Elite & 7382.3 & 373.4 & 3772.1 & 161.8 & 3610.3 & 48.9 & 1.13 & 1.07 & 62.5 & -461.0 \\
\hline 23 - PH 4 & 5501.4 & -297.5 & 2431.5 & -638.4 & 3069.9 & 55.8 & 0.94 & 1.23 & 49.7 & -1000.1 \\
\hline 24 - Cunha & 5776.7 & -50.8 & 2576.1 & -624.6 & 3200.7 & 55.4 & $0.11 * *$ & $5.45^{* *}$ & 0.3 & -1218.2 \\
\hline 25 - BA III- Tusón & 3865.3 & -633.0 & 2118.8 & 372.2 & 1746.6 & 45.2 & 0.74 & 1.52 & 33.2 & -1965.2 \\
\hline 26 - Saracura & 7613.5 & 330.4 & 3500.0 & -613.5 & 4113.5 & 54.0 & 1.31 & 0.43 & 84.8 & -143.8 \\
\hline 27 - Nitroflint & 7234.8 & 303.2 & 3359.7 & -515.4 & 3875.1 & 53.6 & 0.92 & 1.47 & 44.4 & -468.1 \\
\hline 28 - Nitrodent & 7568.5 & 478.0 & 3501.1 & -566.4 & 4067.5 & 53.7 & 1.17 & 1.59 & 54.3 & -483.9 \\
\hline
\end{tabular}

$\hat{\overline{\mathrm{S}}}_{\mathrm{i}}$ : mean ear weight $(\mathrm{kg} / \mathrm{ha})$ in the 10 environments of the panmitic population; $\hat{\overline{\mathrm{g}}}_{\mathrm{i}}$ : estimate of the general combining ability effects in the 10 environments; $\hat{\overline{\mathrm{S}}}_{\mathrm{i}}$ : mean ear weight $(\mathrm{kg} / \mathrm{ha})$ in the 10 environments, in the population after one generation of selfing; $\hat{\mathrm{u}}+\hat{\mathrm{a}}=\mathrm{L}_{\mathrm{i}}=2 \hat{\overline{\mathrm{S}}}_{\mathrm{i}}-\hat{\overline{\mathrm{S}}}_{\mathrm{j}}$ : mean of the lines extracted from the $\mathrm{i}^{\text {th }}$ population; $\hat{\overline{\mathrm{S}}}_{\mathrm{i}}-\hat{\overline{\mathrm{S}}}_{\mathrm{i}}$ inbreeding depression; ID\%: is the percentage of inbreeding depression caused by self pollination of the $\mathrm{i}^{\text {th }}$ population, measured in relation to the mean of the $\mathrm{i}^{\text {th }}$ population; $\beta_{1}$ : adaptability coefficient of Eberhart and Russell for inbreeding depression; $\mathrm{F}_{\text {dev }}$ : $\mathrm{F}$ test for the deviation from regression in the Eberhart and Russell methodology (1966) and $\mathrm{R}^{2}$ : coefficient of determination; $\hat{\overline{\mathrm{s}}}_{\mathrm{ii}}$ : estimate of the specific combining ability of the $i^{\text {th }}$ population crossed with itself as an average of the 10 environments.

where $y_{i j k}$ is the adjusted mean of the $i^{\text {th }}$ population in the $j^{\text {th }}$ environment; $\mu$ is the general mean; $g_{i}$ : is the effect of the $i^{\text {th }}$ treatment, with $\mathrm{i}=1,2, \ldots, \mathrm{G} ; \mathrm{a}_{\mathrm{j}}$ is the effect of the $\mathrm{j}^{\text {th }}$ environment, with $\mathrm{j}=1,2, \ldots, \mathrm{A}$; $(\mathrm{ga})_{\mathrm{ij}}$ is the effect of the of the $\mathrm{i}^{\text {th }}$ treatment interaction with the $\mathrm{j}^{\text {th }}$ environment and $\bar{\varepsilon}_{\mathrm{ij}}$ is the random error associated with the $\mathrm{y}_{\mathrm{ijk}}$ observation.

The previous model was associated with the following restrictions and assumptions:

$$
\sum_{\mathrm{i}=1}^{\mathrm{G}} \mathrm{g}_{\mathrm{i}}=\sum_{\mathrm{i}=1}^{\mathrm{G}} \mathrm{ga}_{\mathrm{ij}}=0 \text {, for each } \mathrm{j}
$$

$$
\begin{aligned}
& \mathrm{a}_{\mathrm{ij}} \sim \operatorname{NID}\left(0, \sigma_{\mathrm{a}}^{2}\right) ; \\
& \mathrm{ga}_{\mathrm{ij}} \sim \operatorname{NID}\left(0, \sigma_{\mathrm{ga}}^{2}\right) ; \text { and } \\
& \varepsilon_{\mathrm{ij}} \sim \operatorname{NID}\left(0, \sigma^{2}\right),
\end{aligned}
$$

Inbreeding depression was studied using the methodology developed by Gardner (1965) and presented in detail by Vencovsky and Barriga (1992). The means of random mating population $(\overline{\mathrm{P}})$ and pure lines $(\overline{\mathrm{L}})$ obtained from successive self-pollination from plants randomly extracted from this population, based on the additive-dominant model, can be expressed as: 
Table IV - Pearson's correlation coefficients among the estimates of seven parameters obtained from the diallel and the inbreeding depression analysis for ear weight $(\mathrm{kg} / \mathrm{ha})$ of 28 maize populations assessed in 10 environments.

\begin{tabular}{lcccccc}
\hline & $\hat{\overline{\mathrm{g}}}_{\mathrm{i}}$ & $\hat{\overline{\mathrm{S}}}_{\mathrm{i}}$ & $\hat{\mathrm{u}}+\hat{\mathrm{a}}$ & $\hat{\overline{\mathrm{S}}}_{\mathrm{i}}-\hat{\overline{\mathrm{S}}}_{\mathrm{i}}$ & $\mathrm{ID} \%$ & $\hat{\overline{\mathrm{S}}}_{\mathrm{ii}}$ \\
\hline$\hat{\overline{\mathrm{S}}}_{\mathrm{i}}$ & $0.86^{*}$ & $0.79^{*}$ & 0.05 & $0.76^{*}$ & 0.04 & $0.67^{*}$ \\
$\hat{\overline{\mathrm{g}}}_{\mathrm{i}}$ & & $0.75^{*}$ & 0.16 & $0.58^{*}$ & -0.08 & 0.20 \\
$\hat{\overline{\mathrm{S}}}_{\mathrm{i}}$ & & $0.66^{*}$ & 0.20 & $-0.58^{*}$ & $0.42^{*}$ \\
$\hat{\mathrm{u}}+\hat{\mathrm{a}}$ & & & $-0.61^{*}$ & $-0.98^{*}$ & -0.14 \\
$\hat{\overline{\mathrm{S}}}_{\mathrm{i}}-\hat{\overline{\mathrm{S}}}_{\mathrm{i}}$ & & & & & $0.67^{*}$ & $0.62^{*}$ \\
$\mathrm{ID} \%$ & & & & & 0.19 \\
\hline
\end{tabular}

*, Indicate $\mathrm{t}$ test significant at $5 \%$ levels of probability; $\hat{\overline{\mathrm{S}}}_{\mathrm{i}}$ : mean ear weight $(\mathrm{kg} / \mathrm{ha})$ in the 10 environments of the panmitic population; $\hat{\overline{\mathrm{g}}}_{\mathrm{i}}$ : estimate of the general combining ability effects in the 10 environments; $\hat{\overline{\mathrm{S}_{\mathrm{i}}}}$ : mean ear weight $(\mathrm{kg} / \mathrm{ha})$ in the 10 environments, in the population after one generation of selfing; $\hat{u}+\hat{a}=L_{i}=2 \hat{\bar{S}}_{i}-\hat{\bar{S}}_{0 i}$ : mean of the lines extracted from the $i^{\text {th }}$ population; $\hat{\bar{S}}_{\mathrm{i}}-\hat{\overline{\mathrm{S}}}_{\mathrm{i}}$ inbreeding depression; ID\%: is the percentage of inbreeding depression caused by self pollination of the $i^{\text {th }}$ population, measured in relation to the mean of the $i^{\text {th }}$ population; $\hat{\bar{s}}_{\mathrm{ii}}$ : estimate of the specific combining ability of the $i^{\text {th }}$ population crossed with itself as an average of the 10 environments.

$$
\begin{aligned}
& \overline{\mathrm{P}}=\mathrm{u}+\mathrm{a}+\mathrm{d}+\overline{\mathrm{e}}_{0}, \text { and } \\
& \overline{\mathrm{L}}=\mathrm{u}+\mathrm{a}+\overline{\mathrm{e}}_{\mathrm{L}},
\end{aligned}
$$

where a and d are, respectively, contributions of homozygous and heterozygous loci to the original population (0). In the first self-pollinating generation $S_{1}$, the mean is then given by:

$$
\overline{\mathrm{S}}_{1},=\mathrm{u}+\mathrm{a}+\frac{\mathrm{d}}{2}+\overline{\mathrm{e}}_{1}
$$

The difference between the panmitic population mean $\left(\overline{\mathrm{S}}_{0 \mathrm{i}}\right)$ and the population mean after one generation of self-pollination $\left(\overline{\mathrm{S}}_{1 \mathrm{i}}\right)$ is an estimate of inbreeding depression (ID) which, under the assumption of no epistasis, correspond to:

$$
\overline{\mathrm{S}}_{0 \mathrm{i}}-\overline{\mathrm{S}}_{1 \mathrm{i}}=\frac{1}{2} \hat{\mathrm{d}}
$$

Inbreeding depression can be measured in relation to the mean of the $\mathrm{i}^{\text {th }}$ population:

$$
\mathrm{ID} \%=\left[\frac{\left(\overline{\mathrm{S}}_{0 \mathrm{i}}-\overline{\mathrm{S}}_{1 \mathrm{i}}\right)}{\overline{\mathrm{S}}_{0 \mathrm{i}}}\right] .100
$$

Estimation of population's inbreeding depression is important because it relates to the vigor of lines extractable from such a population. The greater the $\hat{d}$ participation in the mean of the original population, the greater will be the reduction in the mean of the inbred lines, a possible compli- cation for a program that emphasizes hybrids, since the mean of the set of all lines is a function of â.

Assessment of the first pollination generation of parents included in the diallel allows, therefore estimation of their respective inbreeding depression, and may provide important information about the set means of all lines extracted from these populations. The mean may be obtained from the following expression:

$$
\overline{\mathrm{L}}_{\mathrm{i}}=(\hat{\mathrm{u}}+\hat{\mathrm{a}})_{\mathrm{i}}=2 \overline{\mathrm{S}}_{1 \mathrm{i}}-\overline{\mathrm{S}}_{0 \mathrm{i}} \text {. }
$$

The diallel data used in this paper was previously discussed by Pacheco et al. 1999. In this last paper a methodology to breakdown the Eberhart and Russell (1966) parameters of adaptability and stability (regression coefficient and regression deviation) was described. These parameters were breakdown into three components estimated by Griffing (1956) methodology. These components are: a) the mean; $b$ ) the additive genetic effects ( $g_{i}$ 's and $g_{j}$ 's $)$; $\left.c\right)$ the dominance effects $\left(\mathrm{s}_{\mathrm{ij}}{ }^{\prime}\right)$. This methodology makes possible to study the stability and adaptability using Griffing parameters obtained from diallels conducted in a series of environments.

The behaviour of the population concerning inbreeding depression as a function of environmental variations was studied using a stability and adaptability analysis (Ebehart and Russel, 1966) in the data of $\left(\hat{\overline{\mathrm{S}}}_{0 \mathrm{i}}-\hat{\overline{\mathrm{S}}}_{1 \mathrm{i}}\right)$ from the environments.

\section{Results and Discussion}

Significant $\mathrm{F}$ tests for all factors, except the S1's x environment interaction, in the combined analysis of variance were detected. Inbreeding depression of the treatments differed significantly, also varying with environments (Table II).

Discussions based on mean results will be emphasized although the significance of the inbreeding depression $\mathrm{x}$ environment interaction was significant. This option is justified by the assumption that the environments were considered a random effect and in this case, although variations exist from one environment to another, the general mean may be considered as a good estimator for assessing inbreeding depression effects in the studied populations. This is also the most desirable for the breeding programs, which rarely assess performance of inbred progenies 'per se' in more than one environment during the line development process.

Estimates of inbreeding depression of the 28 populations across 10 environments are presented in Table III. Mean yields for the panmitic populations $\left(\hat{\overline{\mathrm{S}}}_{0 \mathrm{i}}\right)$, mean yields for the populations after one self-pollinating generation $\left(\hat{\overline{\mathrm{S}}}_{1 \mathrm{i}}\right)$, estimates of the means of possible lines extracted from these populations $\left(2 \mathrm{~S}_{1 \mathrm{i}}-\mathrm{S}_{01}\right)$, inbreeding depression estimated by $\left(\hat{\bar{S}}_{0 \mathrm{i}}-\hat{\overline{\mathrm{S}}}_{1 \mathrm{i}}\right)$, inbreeding depression percentage, 
GCA $\left(\hat{\overline{\mathrm{g}}}_{\mathrm{i}}\right)$ and SCA effects of the population with itself $\left(\hat{\overline{\mathrm{s}}}_{\mathrm{ii}}\right)$, are also shown in Table III.

The estimates of $\left(2 \mathrm{~S}_{1 \mathrm{i}}-\mathrm{S}_{01}\right)$ show that the more productive lines, due to higher frequency of favorable alleles, would be derived from BR-105, BR-111, CMS-01, CMS03, and BR-106. An almost perfect inverse relationship was found $(r=-0.98)$ between estimated mean of the lines and percentage of inbreeding depression in these populations. Regarding that, the greater the reduction in mean yield due to inbreeding, the smaller the expected mean for the lines extracted from a population (Table IV).

The negative estimates for $\left(2 \mathrm{~S}_{1 \mathrm{i}}-\mathrm{S}_{01}\right)$ are probably due to estimation errors of $(\hat{\mathrm{u}}+\hat{\mathrm{a}})$ and to the genetic model adopted for their estimation, which disregards epistasis (Vencovsky and Barriga, 1992). Because $\mathrm{L}_{\mathrm{i}}=2 \hat{\overline{\mathrm{S}}}_{1 \mathrm{i}}-\hat{\overline{\mathrm{S}}}_{0 \mathrm{i}}$, positive results clearly depend on inbreeding percentage not surpassing $50 \%$ after one generation of self-pollination, $(\hat{\mathrm{u}}+\hat{\mathrm{a}})$; it was, however, negative in 16 of the 28 populations evaluated.

Pearson's correlation coefficients among values shown in Table III are given in Table 4. An association of inbreeding depression $\left(\hat{\bar{S}}_{0 \mathrm{i}}-\hat{\overline{\mathrm{S}}}_{1 \mathrm{i}}\right)$ with the other factors, except for $\hat{\bar{S}}_{1 \mathrm{i}}$ was found, as shown by the correlation column: the greater the population yield, the greater the inbreeding depression. But, the greater the inbreeding depression, the lower was the estimated mean for lines extracted from the population, as already mentioned.

Attention should be given, however, to the relatively high correlations between inbreeding depression $\left(\hat{\overline{\mathrm{S}}}_{0 \mathrm{i}}-\hat{\overline{\mathrm{S}}}_{1 \mathrm{i}}\right)$ and the genetic effects of $\hat{\overline{\mathrm{g}}}_{\mathrm{i}}$ and $\hat{\overline{\mathrm{s}}}_{\mathrm{ii}}$. According to Cruz and
Vencovsky (1989), this is probably because both $\hat{\overline{\mathrm{g}}}_{\mathrm{i} \text { 's }}$ and $\hat{\overline{\mathrm{S}}}_{\text {ii's }}$ depend on the variety heterosis $\left(\hat{\overline{\mathrm{h}}}_{\mathrm{i}}\right.$, in Gardner and Eberhart (1966) model), which in turn, is associated with deviations from dominance. Pacheco (1997) studied diallel analysis results of the same 28 populations and concluded that dominance deviations were mainly positive. The large estimate at $\hat{\overline{\mathrm{g}}}_{\mathrm{i}}$ for BR-105 was principally due to the homozygous loci contribution $\left(\hat{\overline{\mathrm{s}}}_{\mathrm{ii}}=-7.3\right)$, while in the BR-106 a high frequency of favorable homozygous alleles was associated with a large contribution of heterozygous loci $\left(\hat{\overline{\mathrm{s}}}_{\mathrm{ii}}=-1048.7\right)$. This agrees with the predicted mean of the lines from each of these populations, which was greater for population BR-105 (Table III).

The interpretation based on homozygous loci and heterosis, however, is not so simple for other populations. The CMS-01, for example, had the lowest percentage of yield reduction caused by inbreeding (34.6\%). CMS-01 had a $\hat{\bar{g}}_{\mathrm{i}}$ estimate equal to -515.8 , showing a high frequency of recessive homozygous loci, and $\hat{\overline{\mathrm{s}}}_{\mathrm{ii}}=-1320.0$ showing high varietal heterosis. We concluded that, in spite of a high recessive allele frequency, CMS-01 showed good genetic complementation when crossed with other materials as shown by the mean of population crosses. Furthermore, with the help of the percentage of inbreeding depression, we further state that its frequency of deleterious alleles that, generally, are recessive, is probably low. Then, CMS-01 can be considered rich in useful "unfavorable alleles in homozigozis" in the exploration of the heterosis; in other words, it exhibits high frequency of recessive forms of favorable alleles in homozygosis. Thus, the inbreeding de-

Table $\mathbf{V}$ - Changes in ear weight mean and in percentage of inbreeding depression of the 10 populations after one generation of selfing compared with the results obtained by Vianna et al. (1982) at Sete Lagoas, MG.

\begin{tabular}{|c|c|c|c|c|c|c|c|c|c|c|}
\hline \multirow[t]{3}{*}{ Treatment } & \multirow[t]{3}{*}{ C.S* } & \multicolumn{6}{|c|}{ Evaluation } & \multirow{2}{*}{\multicolumn{3}{|c|}{$\begin{array}{c}\text { Difference (\%) } \\
(1996-1982)\end{array}$}} \\
\hline & & \multicolumn{3}{|c|}{1996} & \multicolumn{3}{|c|}{1982} & & & \\
\hline & & $\hat{\overline{\mathrm{S}}}_{\mathrm{i}}$ & $\hat{\overline{\mathrm{S}}}_{\mathrm{i}}$ & $\mathrm{ID} \%$ & $\hat{\overline{\mathrm{S}}}_{\mathrm{i}}$ & $\hat{\overline{\mathrm{S}}}_{\mathrm{i}}$ & ID $\%$ & $\hat{\overline{\mathrm{S}}}_{\mathrm{ij}}$ & $\hat{\overline{\mathrm{S}}}_{\mathrm{i}}$ & ID $\%$ \\
\hline 01 - CMS 1 & 1 & 5583 & 3518 & 37 & 5240 & 3200 & 39 & 7 & 10 & -5 \\
\hline 02 - CMS 2 & 1 & 5774 & 3389 & 42 & 5130 & 3140 & 39 & 13 & 8 & 9 \\
\hline $03-\mathrm{CMS} 3$ & 1 & 6533 & 4074 & 38 & 5850 & 3540 & 40 & 12 & 15 & -4 \\
\hline 06 - BR 105 & 9 & 8654 & 5520 & 34 & 4940 & 3410 & 31 & 75 & 62 & 11 \\
\hline 09 - BR 111 & 5 & 7016 & 5172 & 24 & 5670 & 2910 & 49 & 24 & 78 & -50 \\
\hline 10 - BR 112 & 5 & 5989 & 4256 & 29 & 5500 & 3420 & 38 & 9 & 24 & -25 \\
\hline $11-\mathrm{CMS} 14 \mathrm{C}$ & 5 & 6119 & 4698 & 22 & 6020 & 3090 & 49 & 2 & 52 & -55 \\
\hline 12 - CMS 15 & 1 & 7214 & 4049 & 43 & 5400 & 3470 & 36 & 34 & 17 & 20 \\
\hline $13-\mathrm{CMS} 22$ & 8 & 6295 & 3684 & 41 & 4860 & 3170 & 35 & 30 & 16 & 17 \\
\hline $14-\mathrm{CMS} 23$ & 1 & 5313 & 3311 & 38 & 4300 & 2760 & 36 & 24 & 20 & 6 \\
\hline
\end{tabular}

C.S.: Number of cycles of selection; $\hat{\overline{\mathrm{S}}}_{\mathrm{i}}$ mean ear weight $(\mathrm{kg} / \mathrm{ha})$ of the panmitic population; $\hat{\overline{\mathrm{S}}}_{\mathrm{i}}$ : mean ear weight $(\mathrm{kg} / \mathrm{ha})$ of the population after one generation of self pollination; ID\%: percentage of inbreeding depression generated by self pollination of the $\mathrm{i}^{\text {th }}$ population, measured in relation to the mean of the $i^{\text {th }}$ population. 
pression percentage seems to be a good indicator of the quality of the recessive alleles in a population, or their genetic load (Vencovsky and Barriga, 1992).

The objective of this study was to determine inbreeding depression in the assessed populations in order to estimate their potential for line extraction, and also to aid breeders in choosing parents for a recurrent reciprocal selection program. One point has already been reported by Vianna et al. (1982) and Lima et al. (1984), who mention that populations with a wider genetic base and never exposed to inbreeding tend to show greater inbreeding depression when self pollinated compared with populations with a narrower genetic base, obtained from random mating and recombination of inbred lines.

Saracura, Nitrodent, Nitroflint, and CMS-39 populations, with demonstrated potential for a breeding program, are among those showing a wider genetic base within the initial set of 28 population group due to an inbreeding depression near 50\%. Examples of populations with a narrower genetic base include: BR-105 and Sintético Elite, formed by 16 and 20 inbred lines, respectively. These two populations had inbreeding depressions of $39.1 \%$ and $48.9 \%$, respectively. The lower inbreeding value for BR-105 may be attributed to a long established, intense selection program, with various selection cycles using S1 progenies (Santos et al., 1994).

Since inbreeding depression $\mathrm{x}$ environments interaction was significant (Table II), we analyzed adaptability and stability (Eberhart and Russell, 1966) for the inbreeding depression. The objective of this analysis was to obtain information on differential deviation of inbreeding depression of the populations across environments. Eighteen populations showed stable inbreeding depression or predictable environmental reactions, based on nonsignificant regression deviations. According to environmental stimulus response, three population (CMS $04 \mathrm{~N}$, CMS $04 \mathrm{C}$ and CMS 28) showed highly increase in inbreeding depression when the environmental stimulus increased from the less favorable environments for the more favorable ones $\left(\beta_{1}>1.0\right)$; two populations (CMS 01 and Cunha) presented a significant $t$ test for $\beta_{1}<1.0$ while nonsignificant for $\beta_{1}=0.0$, with a total lack of response of inbreeding depression to environmental stimuli; in the other 23 populations, inbreeding depression has shown a uniform response to environmental stimuli $\left(\beta_{1}=1.0\right)$. From these results, it can be concluded that the complex component of the interaction (due to the low correlation between treatment means from one location to another as mention by Vencovsky and Barriga, 1992) could be less important than the simple component of the interaction, what would imply that for the majority of the populations, the advance of level of inbreeding in a single environment could be recommended. The use of Eberhart and Russell's (1966) methodology with inbreeding depression data generally revealed weak adjustment to linear regression, only Saracura and BR-107 populations showed $\mathrm{R}^{2}$ exceeding $80 \%$ (Table III).

Although the genotypes $\mathrm{x}$ years interaction is as important as genotypes $\mathrm{x}$ locations interaction for quantitative traits, such as ear weight, some important inferences can be made concerning differences between results found here and those of Vianna et al. (1982) for the ten populations that were in common between the two seasons of evaluation in Sete Lagoas. Consider the populations submitted to more than one cycle of selection in the period between the two studies, the BR-105 population exhibited a greater mean change compared with random mating $\left(\mathrm{S}_{0}\right)$. Population BR-105, however, had the least inbreeding depression in 1982 (Table V), attributable to its origin based on the recombination of $16 \mathrm{~S} 1$ progenies. This population was considered by Vianna et al. (1982) the best source of lines with good performance per se, due to the largest $(\hat{\mathrm{u}}+\hat{a})$ estimate, despite of its narrower genetic base. After nine cycles of selection, population BR-105 continues to be the best source of lines per se, and one of the two best populations evaluated (Table II). These data reinforce the importance of inbreeding depression estimation as an aid for breeders in choosing populations for breeding programs.

The BR-111 population from 1982 to 1996, showed a greater increase in the $\mathrm{S}_{1}$ mean, with substantial reduction of inbreeding depression after five cycles of selection (49\% in 1982 and $24 \%$ in 1996). However, the $\mathrm{S}_{0}$ mean did not follow the same advance (Table V). Possibly in BR-111 selection acted more efficiently on heterozygous loci than on homozygous loci. This was evident when comparing its general combining ability with that of BR-105, but BR-111 was as promising as BR 105 for line extraction (Table III).

Similarly CMS-14C, which in 1982 was the population with the highest mean and largest inbreeding depression, after five cycles of selection in acid soils from savannah area, showed the largest reduction in inbreeding depression among the 10 populations between the 1982 and 1996 studies. However, it showed the least change in the $\mathrm{S}_{0}$ mean (Table5).

Comparisons among BR-105, BR-111, and CMS$14 \mathrm{C}$ showed that inbreeding depression may decrease in two ways: at the cost of small gains in the $\mathrm{S}_{0}$ mean or increase of the population mean after one generation of selfing. These two cases seem to depend on the type of predominant gene action in the population, the genetic frequency, the selection method used in breeding, and the environment chosen for selection and evaluation. The ideal solution seems be synthetics with a narrower genetic base associating low inbreeding depression (small genetic load) with high potential for line extraction, reflecting equilibrium between additive and dominant effects.

Finally, when the mean allelic frequency of a diallel equals to 0.5 , the dominance effects are cancelled, so that the $\hat{\bar{g}}_{i}$ is strictly a function of additive effects and genetic frequency in the $i^{\text {th }}$ parent. In this case variety heterosis will 
not be present unless epistasis occurs. Genetic frequency in this diallel was probably different from 0.5 , given the existence of the varietal heterosis responsible for the variation in $\hat{\overline{\mathrm{s}}}_{\mathrm{ii}}$. This idea, according to Vencovsky and Barriga (1992), is reinforced when the correlation $(0.16)$ between $\hat{\bar{g}}_{i}$ and $(\hat{\mathrm{u}}+\hat{\mathrm{a}})$ is low, as in this study.

\section{Conclusions}

- The study of inbreeding depression revealed that, among assessed populations, lines with higher means should be obtained from BR-105, BR-111, CMS-01, CMS-03, BR-106, CMS-14 C, and CMS-28 populations.

- Inbreeding depression was higher in populations with a wider genetic base never exposed to inbreeding, especially BR-107, CMS-30, PH4, Cunha, Saracura, Nitrodent, and Nitroflint.

- The study of inbreeding depression associated with analysis of diallel crosses in maize populations was an important tool in interpreting genetic parameters and in selecting parents for intra- and inter-population breeding programs.

\section{References}

Crow JF and Kimura M (1970) An Introduction to population genetics theory. Harper \& Row, Publ., New York, 591 pp.

Cruz CD and Vencovsky R (1989) Comparação de alguns métodos de análise dialélica. R Bras Genet 12:425-438.

Eberhart SA and Russell WA (1966) Stability parameters for comparing varieties. Crop Sci 6:36-40.
Gardner CO (1965) Teoria de genética estadística aplicable a las medias de variedades, sus cruces y poblaciones afines. Fitotec Latinoamer 2:11-22.

Gardner CO and Eberhart SA (1966) Analysis and interpretation of the variety cross diallel and related populations. Biometrics 22:439-452.

Hallauer AR and Miranda Filho JB (1988) Quantitative Genetics in Mayze Breeding. 2nd ed. Iowa State Univ. Press, Ames, Iowa, $468 \mathrm{pp}$.

Lima M, Miranda Filho JB and Gallo PB (1984) Inbreeding depression in Brazilian populations of maize (Zea mays L.). Maydica 29:203-215.

Pacheco CAP (1997) Associação das metodologias de análise dialélica de Griffing e de análise de adaptabilidade e estabilidade de Eberhart e Russell. PhD thesis, Universidade Federal de Viçosa, Viçosa, MG.

Pacheco CAP, Cruz CD and Santos MX (1999) Association between Griffing's diallel and the adaptability and stability analyses of Eberhart and Russell. Genetics and Molecular Biology, 22:451-456.

Santos MX, Pacheco CAP, Gama EEG, Guimarães PEO, Silva AE and Parentoni SN (1994) Seleção recorrente recíproca com progênies de meios-irmãos interpopulacionais obtidas alternadamente em plantas não endógamas $\left(\mathrm{S}_{0}\right)$ e endógamas $\left(\mathrm{S}_{1}\right)$. In: Relatório técnico anual do Centro Nacional de Pesquisa de Milho e Sorgo 1992-1993 6:194.

Vencovsky R and Barriga P (1992) Genética Biométrica no Fitomelhoramento. Sociedade Brasileira de Genética, Ribeirão Preto, $496 \mathrm{pp}$.

Vianna RT, Gama EEG, Naspolini Filho V, Môro JR and Vencovsky R (1982) Inbreeding depression of several introduced populations of maize (Zea mays L.). Maydica 27:151-157. 